\title{
Comparison of CNS vasculitis in children and adults; is this the same disease entity
}

\author{
Marinka Twilt ${ }^{*}$, Carlo Salvarani ${ }^{1}$, Tania Cellucci ${ }^{2}$, Gene G Hunder ${ }^{3}$, Susanne M Benseler ${ }^{2}$ \\ From 2011 Pediatric Rheumatology Symposium sponsored by the American College of Rheumatology \\ Miami, FL, USA. 2-5 June 2011
}

\section{Purpose}

Primary vasculitis of the central nervous system is a newly recognized, devastating inflammatory disease restricted to the brain and spinal cord. Previously healthy children and adults develop life-threatening neurological deficits including stroke and seizures. Within CNS vasculitis distinct disease entities have been identified in different age groups. The aim was to describe the presenting features of children and adults with CNS vasculitis, to compare distinct entities and their treatment regimens between adult and children and to analyze disease progression and/or relapse.

\section{Methods}

Two cohorts of consecutive patients with primary CNS vasculitis based on Calabrese criteria diagnosed over a 21 year period and followed at tertiary vasculitis centers were identified: 1) adult patients (Mayo Clinic, Rochester) and 2) pediatric patients (Sickkids, Toronto). Patient demographic characteristics, presenting clinical features, neuroimaging characteristics, brain pathology results, clinical course including progression and relapse and treatment regimens were recorded. Characteristics of cohorts were analyzed using descriptive statistics. Univariate analysis compared distinct disease phenotypes and treatment regimens. Kaplan Meier survival analysis was performed to determine survival after CNS vasculitis diagnosis.

\section{Results}

A total of 227 patients were included in the study; 101 adult patients and 126 pediatric patients. In children the median age was 8 years (1-17 years) and in adults 47 years (17-84 years). Pediatric patients showed a male predominance (F: $\mathrm{M}=1: 1.5)$ in contrast with the adult cohort (F: $M=1.3: 1)$. Diagnosis was established on angiography only in 88 pediatric and 52 adult patients, and on brain biopsy with negative angiography in 29 pediatric and 8 adult patients. Vessels involved were: in children 35 small vessel and 91 large vessel, in adults 22 small vessel, 6 large vessel and 48 small and large vessels. Brain biopsy: performed in $49 \%$ of adult patients with a male predominance ( $F: M=1: 1.2$ ) compared to $25 \%$ in children with a female predominance ( $F: M=1.9: 1)$. Histology showed only lymphocytic inflammation in children and predominantly a granulomatous pattern in adults (18 granulomatous, 8 lymphocytic, 5 acute necrotizing). Treatment strategies: in children prednisone in 59 (47\%) and cyclophosphamide in $34(27 \%)$, in adults prednisone in 97 (96\%) and cyclophosphamide in 46 patients (46\%). Relapse or progression of the disease was seen in adults in $26 \%$ and in children in $15 \%$.

\section{Conclusion}

Distinct differences are present in the spectrum of primary CNS vasculitis in adults and children. Biopsy only or angiography only confirmed disease shows different gender predominance in adults compared to children. Adults are treated more frequently with steroids and cyclophosphamide, however relapse rates are lower in children.

\section{Disclosure}

Marinka Twilt: None; Carlo Salvarani: None; Tania Cellucci: None; Gene G. Hunder: None; Susanne M. Benseler: None.

\section{Author details \\ ${ }^{1}$ Arcispedale S. Maria Nuova, Reggio Emilia, Italy. ${ }^{2}$ Hospital for Sick Children, Toronto, ON, Canada. ${ }^{3}$ Mayo Clinic, Rochester, MN, USA.}

Published: 13 July 2012 


\section{Reference}

1. Salvarani $C$, et al: Primary central nervous system vasculitis: analysis of 101 patients. Ann Neurol 2007, 62:442-451.

doi:10.1186/1546-0096-10-S1-A83

Cite this article as: Twilt et al: Comparison of CNS vasculitis in children and adults; is this the same disease entity. Pediatric Rheumatology 2012 10(Suppl 1):A83.

Submit your next manuscript to BioMed Central and take full advantage of:

- Convenient online submission

- Thorough peer review

- No space constraints or color figure charges

- Immediate publication on acceptance

- Inclusion in PubMed, CAS, Scopus and Google Scholar

- Research which is freely available for redistribution 